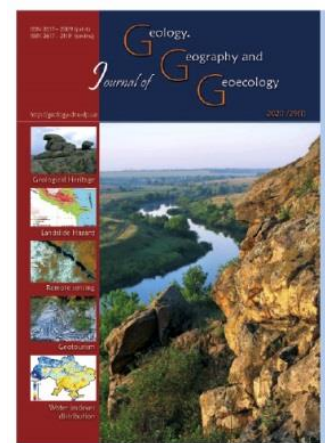

Journal of Geology,

\title{
Geophysical methods for controlling the useful component content as the basis for the quality management system at mining and processing enterprises
}

\author{
Albert A. Azarian ${ }^{1}$, Wolodymyr A. Azarian ${ }^{2}$ \\ ${ }^{1}$ Department of Modeling and Software higher education institution National University of Kryvyi Rih, Kryvyi Rih, \\ Ukraine \\ ${ }^{2}$ Department of Open Mining State higher education institution National University of Kryvyi Rih, Kryvyi Rih, Ukraine, \\ astp165@ukr.net
}

Received: 11.01.2020

Received in revised form: 30.01 .2020

Accepted: 06.02.2020 quality management system for iron ore plants based on geophysical methods of operational quality control for mineral raw materials. Due to the fall in prices on the world markets of iron ore raw materials, the financial and economic situation of the mining and processing enterprises in Ukraine has significantly worsened. Thus, the problem of effective control and quality management in mining has become of maximum importance. The availability of timely and reliable information about the content of the useful component will allow responding quickly, forming an integrated final ore cargo flow of the plant of exact quality required by the mining and concentration complex. The need to create a common quality management system is dictated by the fact that the iron ore has a heterogeneous distribution of the useful component content within the deposit, the extraction and transport equipment operates irregularly, resulting in ore cargo flows of various degrees of integration have significant amplitude and frequency oscillations, both by quality and quantity indicators. The instability of the useful component content in the ore cargo, which is aimed at enrichment, leads to a decrease in concentrate output, increase of losses in the tails, costs increase, decrease of the enterprise profit and decrease of its competitiveness. The mathematical model of ore cargo flow formation, which has a range of limitations on quality characteristics, is given. The structure and functional scheme of the quality management system of the mining and processing plant are substantiated. As a result of theoretical studies, the possibility of using radiometric and magnetometric methods for the operational quality control of the iron ore raw materials in the conditions of mining and processing plants by geophysical devices developed by the staff of the problem-branch laboratory of the Kryvyi Rih National University and Rudpromheofizyka LLC is substantiated. The basic technological characteristics of devices and systems are given, information on their introduction into production is provided. It is concluded that the researches carried out and the devices introduced on their basis have created objective prerequisites for substantiating the quality management system at mining and processing plants. The devices and operational control systems based on geophysical methods allow to cover all major stages of mining and processing, to receive timely and reliable information on the condition and dynamics of changes in the useful component content, to efficiently quality management at mining and processing plants, to increase the enterprises competitiveness and profitability.

Keywords: operational quality control, quality management system, useful component content, ore cargo flow, chemical analysis, logging.

\section{Геофізичні методи контролю вмісту корисного компоненту як основа системи управління якістю гірничо-збагачувальних комбінатів}

\author{
Альберт А. Азарян ${ }^{1}$, Володимир А. Азарян ${ }^{2}$
}

1Кафедра моделювання та програмного забезпечення Державного вищого навчального закладу «Криворізький начіональний університет», Кривий Ріг, Украӥна

2Кафедра відкритих гірничих робіт Державного вищяого навчального закладу «Криворізький начіональний університет», Кривий Piг, Украӥна, astp165@ukr.net

Анотація. Стаття присвячена обгрунтуванню можливості створення загальної системи управління якістю залізорудних комбінатів на основі геофізичних методів оперативного контролю якості мінеральної сировини. Внаслідок падіння цін на 
світових ринках залізорудної сировини фінансово-економічне становище гірничо-збагачувальних комбінатів України значно погіршилося, тому проблема здійснення ефективного контролю та управління якістю в умовах гірничого виробництва набула максимального значення. Наявність своєчасної та достовірної інформації про вміст корисного компоненту дозволить оперативно реагувати, формуючи інтегрований фінальний рудний вантажопотік комбінату саме такої якості, якої потребує збагачувальний комплекс. Необхідність створення загальної системи управління якістю продиктована тим, що залізорудна сировина має неоднорідний розподіл вмісту корисного компоненту в межах родовища, видобувне та транспортне устаткування працює неритмічно, внаслідок чого рудні вантажопотоки різного ступеню інтеграції мають значні амплітудно-частотні коливання як за якісними, так й за кількісними показниками. Нестабільність вмісту корисного компоненту в рудному вантажопотоці, що спрямовується на збагачення, призводить до зниження виходу концентрату, збільшення втрат у хвостах, підвищення витрат, зниження прибутку підприємства та падіння його конкурентоздатності. Наведено математичну модель формування рудного вантажопотоку, що має діапазонні обмеження по якісних характеристиках, обгрунтовано структуру та функціональну схему системи управління якістю гірничо-збагачувального комбінату. В результаті теоретичних досліджень обгрунтовано можливість застосування радіометричних та магнітометричних методів для здійснення оперативного контролю якості залізорудної сировини в умовах гірничо-збагачувальних комбінатів геофізичними приладами, що розроблені колективом проблемно-галузевої лабораторії Криворізького національного університету та ТОВ «Рудпромгеофізика». Наведені основні технологічні характеристики приладів та систем, надані відомості щодо їх впровадження у виробництво. Зроблено висновки, що проведені дослідження та впроваджені на їх основі у виробництво прилади створили об'єктивні передумови для обгрунтування системи управління якістю гірничо-збагачувальних комбінатів. Пристрої та системи оперативного контролю, які основані на геофізичних методах, дозволяють охопити усі основні етапи гірничого виробництва та переробки, отримувати своєчасну та достовірну інформацію про стан та динаміку змін вмісту корисного компоненту, здійснювати ефективне управління якістю гірничо-збагачувальних комбінатів, підвищити конкурентноздатність та прибуток цих підприємств.

Ключові слова: оперативний контроль якості, система управління якістю, вміст корисного компоненту, рудний вантажопотік, хімічний аналіз, каротаж.

Introduction. In the conditions of fierce competition of the world iron ore producers, against the background of deterioration in mining and technological conditions of development of deposits, quality decrease of raw material base in Ukraine and increase of production cost, the problem of effective control and quality management in mining production has become of maximum importance.

Quality fluctuations of iron-containing raw materials within the deposit, due to the morphology of the ore bodies and the presence of many varieties of ore, lead to instability in the useful component content of the ore cargo flow, which is directed to the mining and concentration complex (Joukov, Azarian, 2017).

It is known that ore-concentration plant (OCP) are high inertial production systems tuned to a specific quality index in a given range of oscillations. Excessive fluctuations in the useful component content in the ore at the inlet of OCP, which go beyond the specified calculation range, lead to a decrease in concentrate output, increase in losses in the tails, increase the cost of processing. That is why the instability in the quality characteristics of iron-containing raw materials causes such negative consequences as the decrease in the profit of the oredressing and mining and concentration complex (MCC) and the fall of their competitiveness (Azarian, Joukov, \& Stricha, 2017).

Quality control in the mining and processing of iron ores is to determine the useful component content - that is, raw material quality, as well as to establish other characteristics: density, presence and content of harmful impurities, humidity, etc. For technological control, the main indicator is the content of the useful component, i.e. raw material quality.

Quality control can be carried out either by chemical analysis or using geophysical methods of operational control. The main factor distinguishing the first methods from the second is the speed of information retrieval: chemical analysis methods allow to establish qualitative indicators of minerals over a period of 2 hours, which often increases to 4-6 hours under production conditions, and operational control of one sample is carried out, usually within a few seconds to 3 minutes.

Chemical analysis methods are carried out in accordance with the state standard, so information about the quality characteristics obtained using these methods can be included in the quality certificates, which are the official supporting documents for the shipment of iron ore or products of its processing (concentrate, pellets) under internal or external contracts.

Geophysical methods of operational quality control for iron-containing raw materials are used as technological control, however, due to the speed of obtaining information, their results can be used in the management of extraction, transportation and processing. These methods are indirect control methods: their calibration and tuning are based on chemical analysis data. However, the main advantage of geophysical methods of control in the conditions of iron ore deposits development is their promptness, which allows receiving timely and objective 
information about the quality of raw materials at different stages of production.

The need to create a common quality management system in mining enterprises is dictated by the fact that iron ore has a heterogeneous distribution of useful component content in the deposit, mining and transportation equipment is not rhythmic, resulting in ore cargo flows of varying degrees of integration, and often significant by quantitative indicators, which is extremely negative for such indicators as the concentrate output, its cost and the losses in the tails. The purpose of the research presented in the article is to substantiate the possibility of using devices of geophysical operational quality control for ironcontaining raw materials to create a common quality management system for mining and processing enterprises.

Research methods. The basic methods of mining and the following theories were used to substantiate the quality management system: control, interaction of gamma radiation with rocks, magnetic fields, mathematical statistics and synergetics. Probabilistic and statistical methods were also used, which were applied in the study of the interactions process of gamma-quanta with rocks, as well as in the study of the synergistic effect arising from the combination of operational quality control system with the system of mining and transport dispatching.

Research results and discussions. Modern mining enterprise is a complex system with a developed hierarchical structure, which main purpose is ore extraction. Based on this purpose, requirements for the quality of the raw materials are being formed. The distribution of the useful component content in the mine is often chaotic (Byzov, 1991). However, the final or total ore cargo must have a certain amount of useful component content that does not go beyond the range at any point of time, which is dictated by the requirements of the processing complex.

The mathematical model of control for the formation of the final or total ore flow can be represented in the form of requirements implemented through the quality management system of a mining enterprise. Functional diagram of the ore cargo flow formation is shown in Fig. 1. The total volume of ore is mathematically determined first of all by the capabilities of the ore-dressing complex, and it is a given value:

$$
\sum^{N} m_{k}=m_{0}
$$

where $m_{0}-$ the volume of ore specified at the input of OCP for processing, $t$

$m_{k}-$ quantity of ore delivered by transport from the k-th mine, $\mathrm{t}$;

In turn, according to the technological requirements, the useful component content in the ore after averaging should meet the set value, so there is an equality in quality, which relates these characteristics in the ore in the mines and ore flow:

$$
\sum_{k=1}^{N} c_{k} m_{k}=m_{0} \cdot c_{0},
$$

where $c_{0}-$ the specified ore content after averaging,

$c_{k}$ - useful component content in the ore delivered from the $k$-th mine.

A priori requirement is also the limitation of the ore volumes delivered by transport from the mine in the form of local ore flows:

$$
0 \leq m_{k} \leq \bar{m}_{k}, \quad(k=1,2, \ldots, N)
$$

where $m_{k}$ - the maximum possible volume of ore delivered by transport from the $k$-th mine, t.

Formulas (1), (2) and (3) represent a mathematical model that is a part of the mining management system of a mining enterprise.

Another formulation of this model is possible, in which condition (2) is replaced by the limitation in the amplitude of oscillations for the useful component content in the ore after averaging, that is, after the formation of the ore flow:

$$
c_{\min } \cdot m_{0} \leq \sum_{k=1}^{N} c_{k} m_{k} \leq c_{\max } \cdot m_{0},
$$

where $c_{\min }, c_{\max }-$ minimum and maximum allowable content indices of ore cargo useful component, that is, OCP requirements range limits.

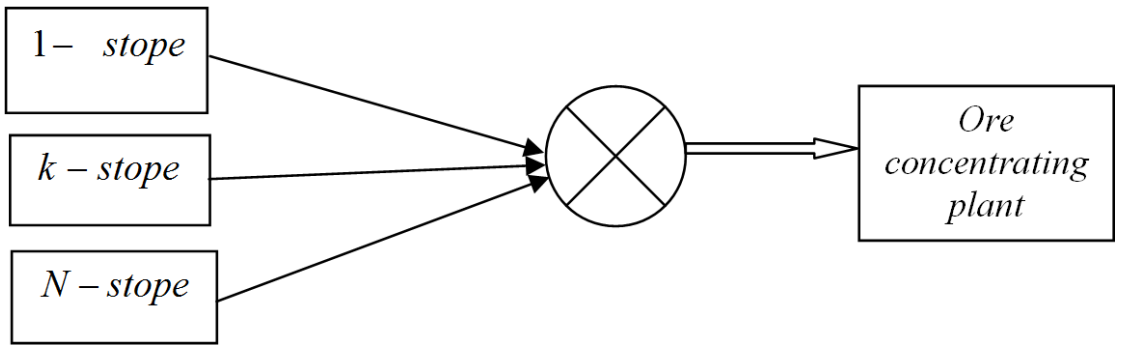

Fig. 1. Functional diagram for the ore cargo formation 
It is known that the management process is a specially organized influence on the object of management in order to obtain the desired result. A device or means producing a control signal to a control object is a control device or control means (Meskon, 1998).

In the MCC quality management system for iron-containing raw materials, such a device is a central server, and the object of control is the process of ore flow formation with the values of the useful component content specified within certain limits.

The control signal (command) produced by the control device (server) is transmitted through the communication channels to the production and transportation facilities, thereby influencing the control object. The set of control object, control device (control mean), information means and controls forms the control system (Meskon, 1998).

In Fig. 2 shows a general scheme for collecting and transmitting prompt information on the useful component content in mining and processing enterprises. quality management for iron-containing raw materials is shown in Fig. 3

The functioning of the quality management system is based on the principle applying averaging as a management method based on reliable and timely information about the useful component content in the mines, ore depots and the final cargo flow, which is obtained through operational control.

In the first stage of quality control logging (additional exploration) of the explosive unit is carried out, which is carried out after the completion of drilling, but before the wells are filled. Logging is a detailed study of the section of the well using the descent-lifting of geophysical probe in it. Gammagamma logging (GGL) refers to nuclear methods of geophysical exploration. The essence of the method is that the rock is irradiated with a source of gamma radiation, after which there is a secondary (scattered) radiation, which allows more efficient study for the parameters of the rock (Artsybashev, Ivanyukovich, 1975). According to the physical basis of the gammagamma method, the magnitude of the integrated flux

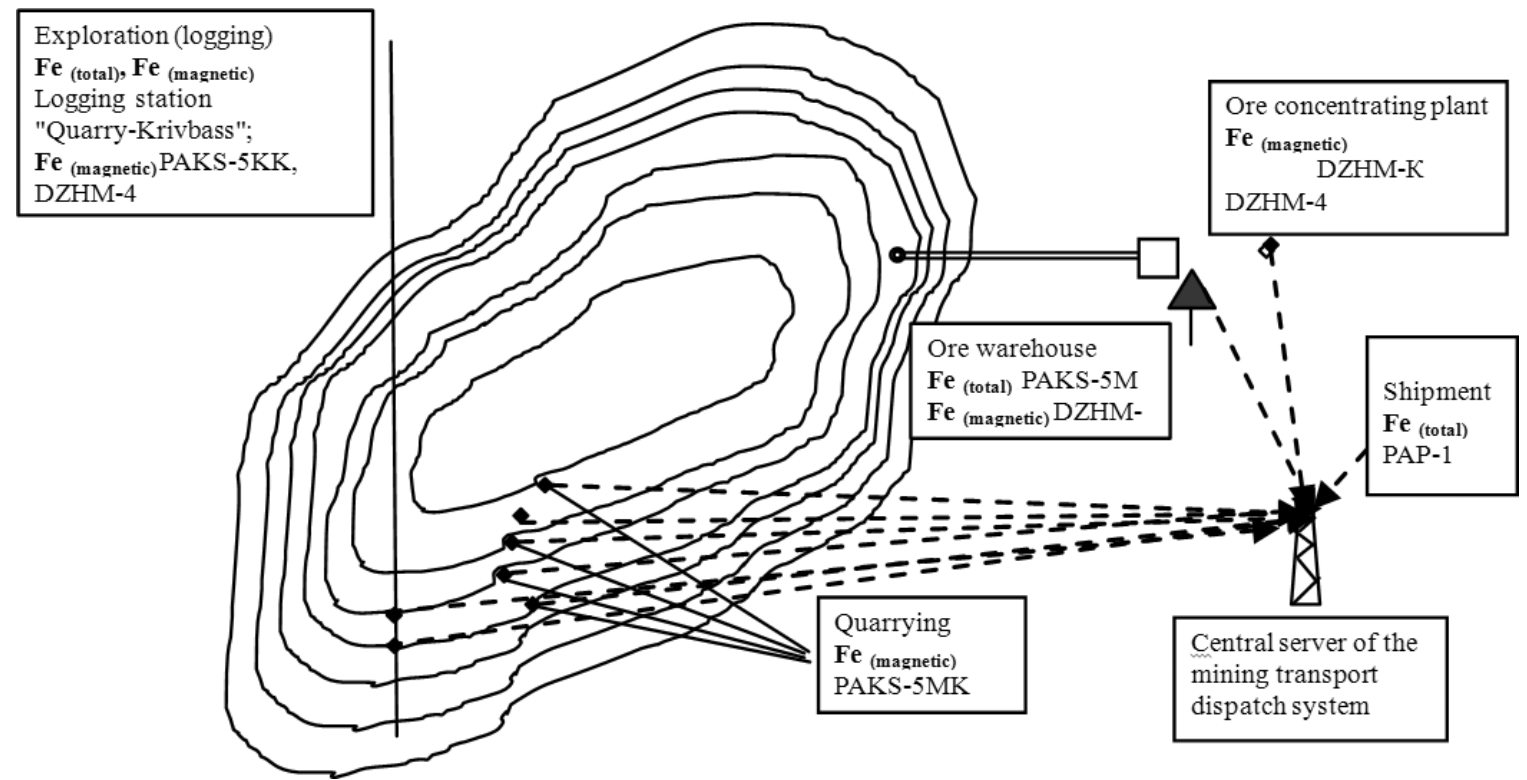

Fig. 2. General scheme of collection and transmission of operational information on the useful component content in the mining and processing enterprises

The quality management of iron-containing raw materials is based on the synergy of control and management systems, consists of quality control systems in mines and transport communications, operational information channels and a central server, which analyzes the situation using the special software, forming a controlling influence in the form of commands to mining and transport means (Azarian, Joukov, 2016). Functional diagram of intensity of scattered gamma radiation, in addition to the effective atomic number, is affected by the density of the investigated medium ( $\rho$ ). If this parameter does not correlate with the useful component content, due to its change, there will be significant distortions in the final results (Morkun, Azarian, \& Azarian, 2015). It has been found that Kryvbas iron ores are characterized by a high correlation between $\rho$ and $\mathrm{Fe}_{\text {tot }}$, which is a favorable precondition for the use of 


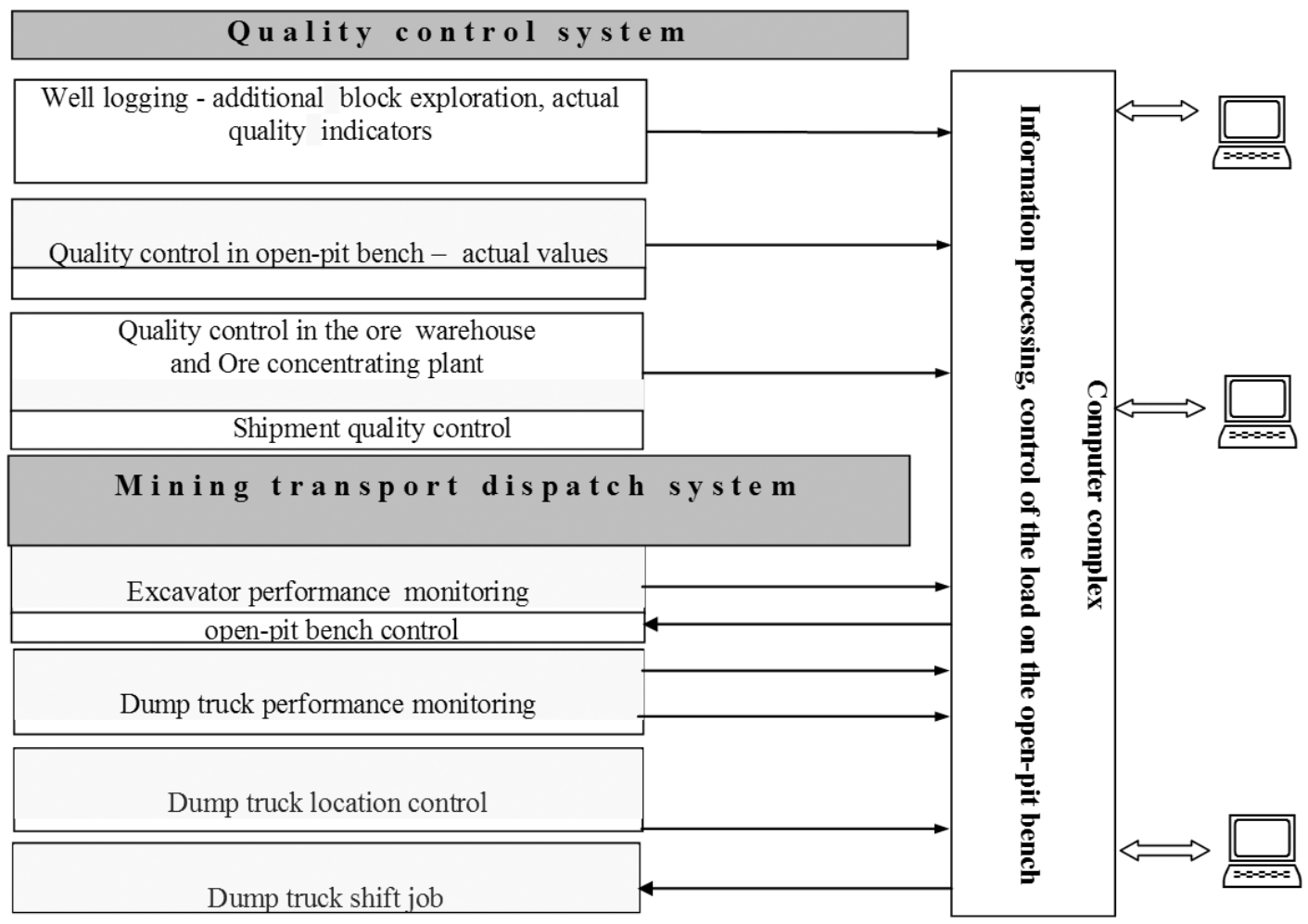

Fig. 3. Functional diagram of quality management for iron-containing raw materials

gamma-gamma logging to determine the total iron in the solid mass. (Morkun, Azarian, \& Azarian, 2015)

A significant factor affecting the accuracy of $\mathrm{Fe}_{\text {tot }}$ determination using gamma-gamma method is the natural humidity of the rocks. According to the statistics, the rich ores of the Kryvyi Rih ironproducing area contain up to $12 \% \mathrm{H}_{2} \mathrm{O}$, while the humidity of the main solid ore varieties ranging from 2 to $8 \%$ (Azarian, Azarian, \& Trachuk, 2016).

Determination of the useful component content using gamma-gamma method is possible not only in the form of logging, but also in piles of blasted rock mass, as well as in laboratory conditions, on preprepared samples (crushed and with a particular level of humidity). In the course of the research, it was found that the intensity of the gamma radiation detected by a receiver depends essentially on the magnitude of the distance between the surface of the ore mass layer and the radiation receiver. The nature of the dependence for the intensity on the distance is largely determined by the design parameters of the sensor: the area of the sensitive surface of the radiation receiver, the diameter of the collimation window of the collimator of the radiation source, the relative location of the receiver and source. Based on the fact that the thickness of the ore layer can vary from 0 to $15 \mathrm{~cm}$, with the stationary placement of the device sensor above the conveyor, the air gap between the radiation receiver and the surface of the ore layer will change within the same limits. This process was modeled, and as a result, the intensity of the scattered gamma radiation recorded by the receiver at different values of the air gap was obtained. The analytical dependence was obtained and plotted using these results (Fig. 4) (Azarian, Azarian, \& Cherkasov, 2015).

The process simulation used an ore sample with an iron content of $58.39 \%$, which is closest to its average value in the ores subject to control. The analysis of the obtained dependence shows that only within the range $H=5 \pm 1.5 \mathrm{~cm}$, with some approximation, it can be assumed that the intensity of the registered gamma radiation does not depend on the magnitude of the air gap. In other words, when changing the thickness of the layer within $3 \mathrm{~cm}$, the error made in measuring the iron content does not exceed $\pm 1 \%$. At higher values of change in the air gap, this error reaches the intensity of $N \approx 500 \mathrm{imp} / \mathrm{cm}$ or $\Delta N \approx 12 \% / \mathrm{cm}$, which is equivalent to an error in the iron content of about $\approx 7-8 \%$ (Azarian, Azarian, \& Trachuk, 2014).

Equally important is the control of the iron content associated with magnetite, which is also carried out in a solid mass (logging), in the heaps of destroyed rock mass and in laboratory conditions. Without quality control of ferrous quartzites, it is impossible to fully operate the MCC quality management system, given that the ore is mainly enriched by magnetic methods. The study of the factors affecting the quality control of ferrous quartzite begins with the study of the magnetic susceptibility of samples. It was found that the specific magnetic susceptibility of magnetite 


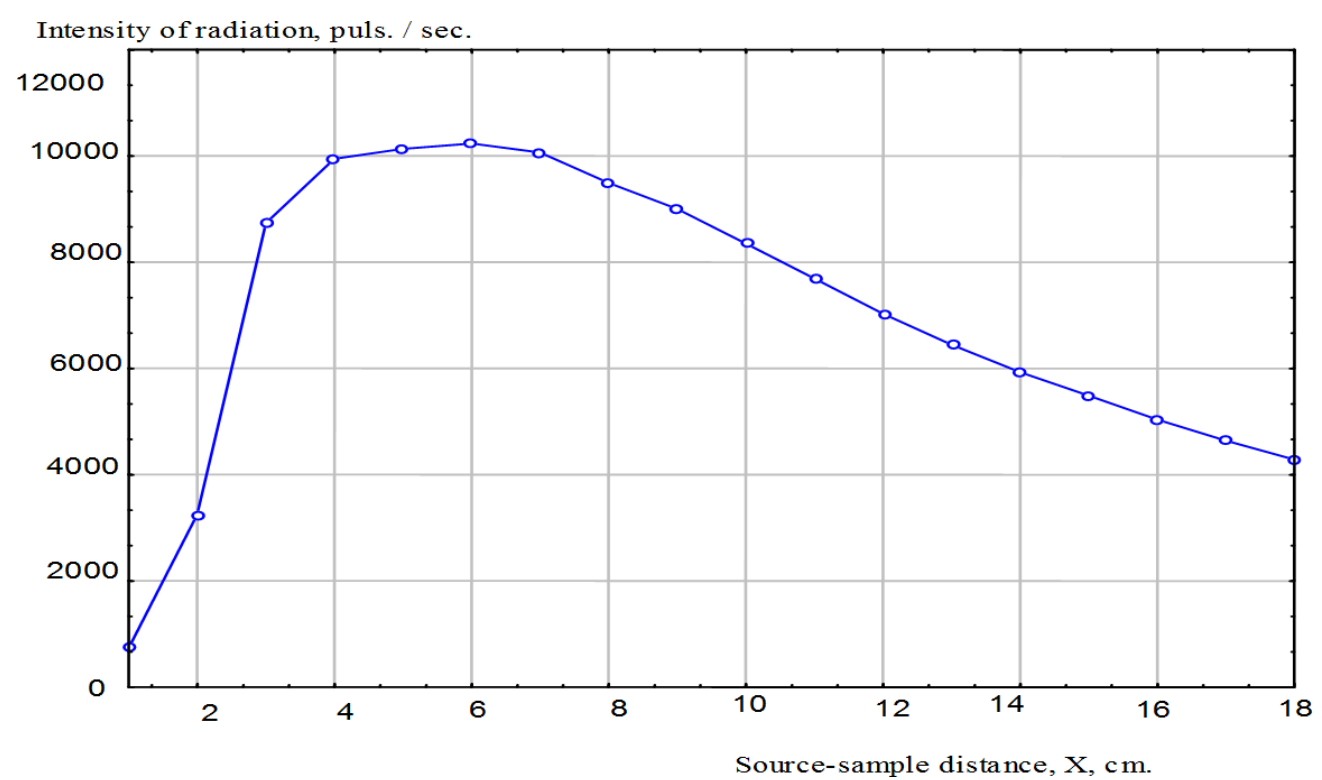

Fig. 4. The dependence of the intensity of the scattered gamma radiation on the distance between the source and the rock mass

$\left(\mathrm{Fe}_{3} \mathrm{O}_{4}\right)$ can fluctuate within $(0.63-1.2) \times 10^{-3} \mathrm{~m}^{3} / \mathrm{kg}$ due to the presence of isomorphic impurities of copper, zinc, manganese and other metals (Azarian, Azarian, $\&$ Cherkasov, 2010). The shape, structure and size of magnetite grains have a significant influence on the measurement, which affects its magnetic susceptibility and coercive force. In addition, changes in the texture and structure of the ores (magnetite grains in nonmagnetic cement or non-magnetic grains in magnetite cement) also affect the magnetic susceptibility of the rock mass. The measurement accuracy is influenced by the change in the conductivity of the magnetite, which ranges from $10^{-1}-10^{-2} \mathrm{~cm} / \mathrm{m}$, the conductivity of non-magnetic metals and the humidity of the controlled sample (Dryga, 2013).

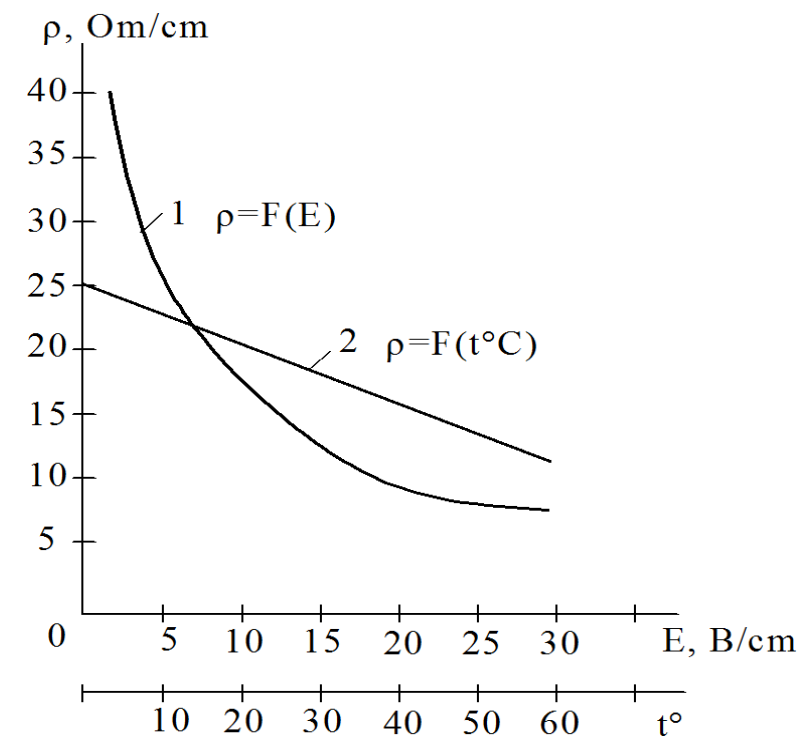

Fig. 5. Dependence of iron ores specific resistance: 1 - from the electric field voltage; $2-$ from the temperature 


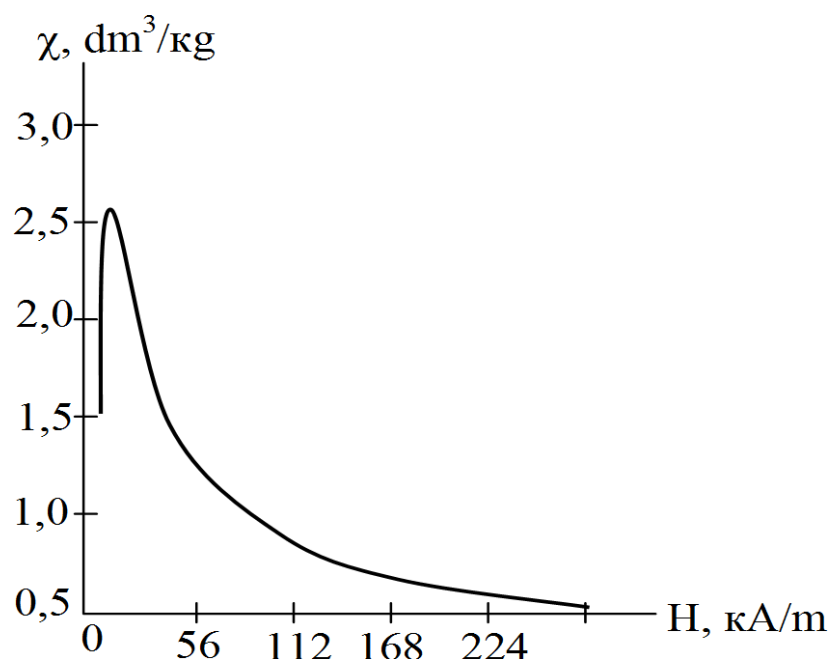

Fig. 6. Dependence of specific magnetic susceptibility $\chi$ of the ore on external field magnetization $H$

the specific magnetic susceptibility $\chi$ of the ore on the external magnetization of the field $H$ - in Fig. 6 , the frequency dependence of the specific resistance of magnetite quartzites - Fig. 7. These dependencies were obtained during studies of ferrous quartzites of the Kryvyi Rih iron-producing area (Azarian, Azarian, \& Cherkasov, 2013).
Rudpromheofizyka LLC and implemented in the production: PAKS-5 M, PAKS-5 MK, PAKS$5 \mathrm{KK}$, Quarry-Kryvbas logging station, sensors for magnetic iron DZHM-4 and DZHM-3 M1, powder samples analyzer PAP-1, as well as of continuous quality control systems of total iron on the NAKS-PK conveyor and magnetic iron control - DZHM-K.

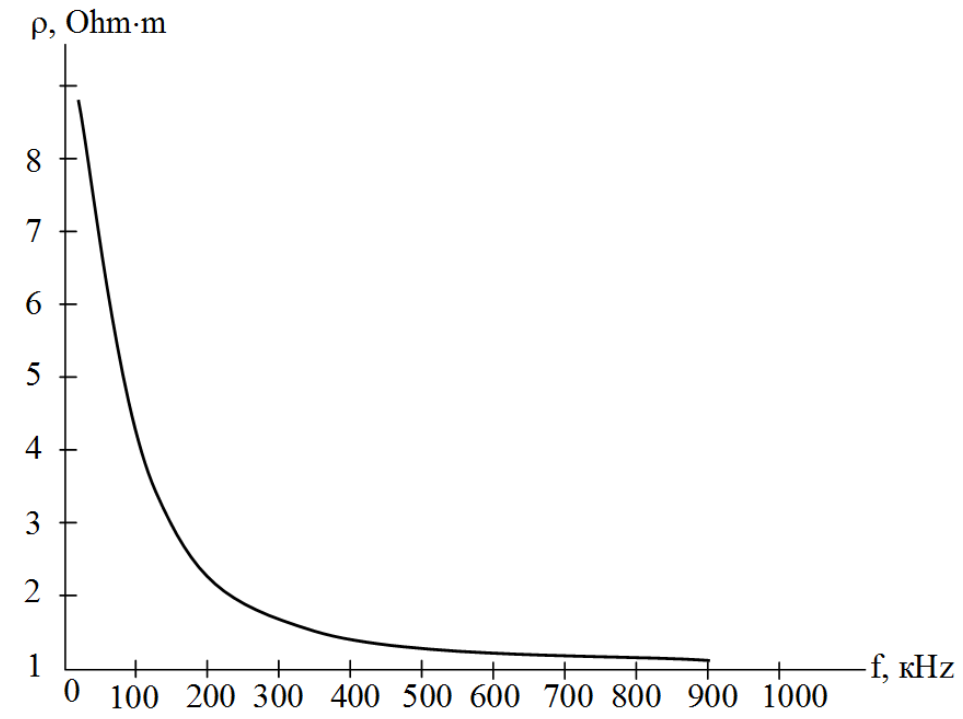

Fig. 7. Frequency dependence of the magnetite quartzites specific resistance

The accuracy of raw material quality measurements for ferruginous quartzites is influenced by the reliability of the correlation between the measured magnetic susceptibility and the magnetite content, as well as the reliability of this relation within individual sections of the deposit (Dryga, 2013).

Hardware of the operational quality control for the content of general and magnetic iron can be geophysical devices, developed by the staff of the problem-branch laboratory of the State Technical University of Kryvyi Rih together with
Well logging is carried out by the Quarry-Kryvbas logging station (Fig. 8). The multifunctional mobile station is used for simultaneous operational control (logging) of the magnetic and total iron content using the method of testing the rock mass in wells up to $100 \mathrm{~m}$ deep (Azarian, Vasilenko, Borodavkin, \& Boyko, 2001). The principle of action is based on the registration of the secondary (reflected) gamma radiation from the walls of the well and simultaneous control for the change of the magnetic field, which occurs in the solid mass as the probe moves. The 


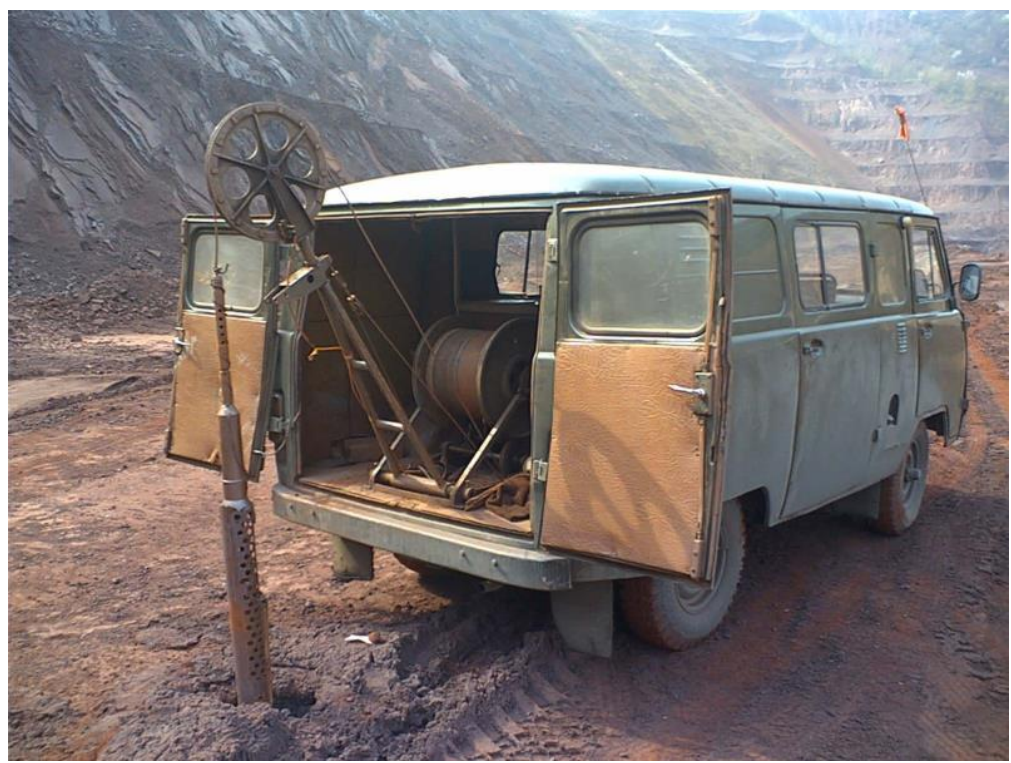

Fig. 8. Quarry-Kryvbas logging station

results of measurements of the useful component content are displayed (as a percentage) on the digital scoreboard of the PAKS radiometer or on the laptop screen. Information on the screen is formed as a table or graph for the dynamics of changes in the useful component content (Azarian, Azarian, Gritsenko, Dryga, \& Miroshnik, 2018). The logging step is variable, it is possible to choose from 0.1 to $1.0 \mathrm{~m}$ depending on the conditions.

The Quarry-Kryvbas logging station provides:

- the exact connection of the well depth and the corresponding value of the useful component content;

- logging for watered wells;

- automatic data recording (date, current time, well depth, total and magnetic iron content values).

The Quarry-Kryvbas logging station controls the useful component content in the range of $1 \div 75 \%$, with an error of $\pm 2.0 \%$ for the total iron and $\pm 1.0 \%$ for the magnetic iron. Power is supplied from the 12 $\mathrm{V}$ on-board network; continuous operation time is not less than 10 hours. Well test after roller-bit drilling in the mines of the Mining Department of PJSC "ArcelorMittal Kryvyi Rih", PJSC "Pivdennyi MCC" and PJSC "Ukrmekhanobr MCC" is being conducted today using the Quarry-Kryvbas logging station.

Logging for magnetic iron can also be carried out separately using a PAKS-5 KK portable device consisting of a measuring console and a log device (Fig. 9).

The criterion for determining the magnetic iron content is the magnetic susceptibility magnitude of the rocks (Azarian, Tsybulevsky, Sharov, Dryga, \& Lisovyj, 2008). The device is paired with the PAKS5 . The principle of the device operation is based on

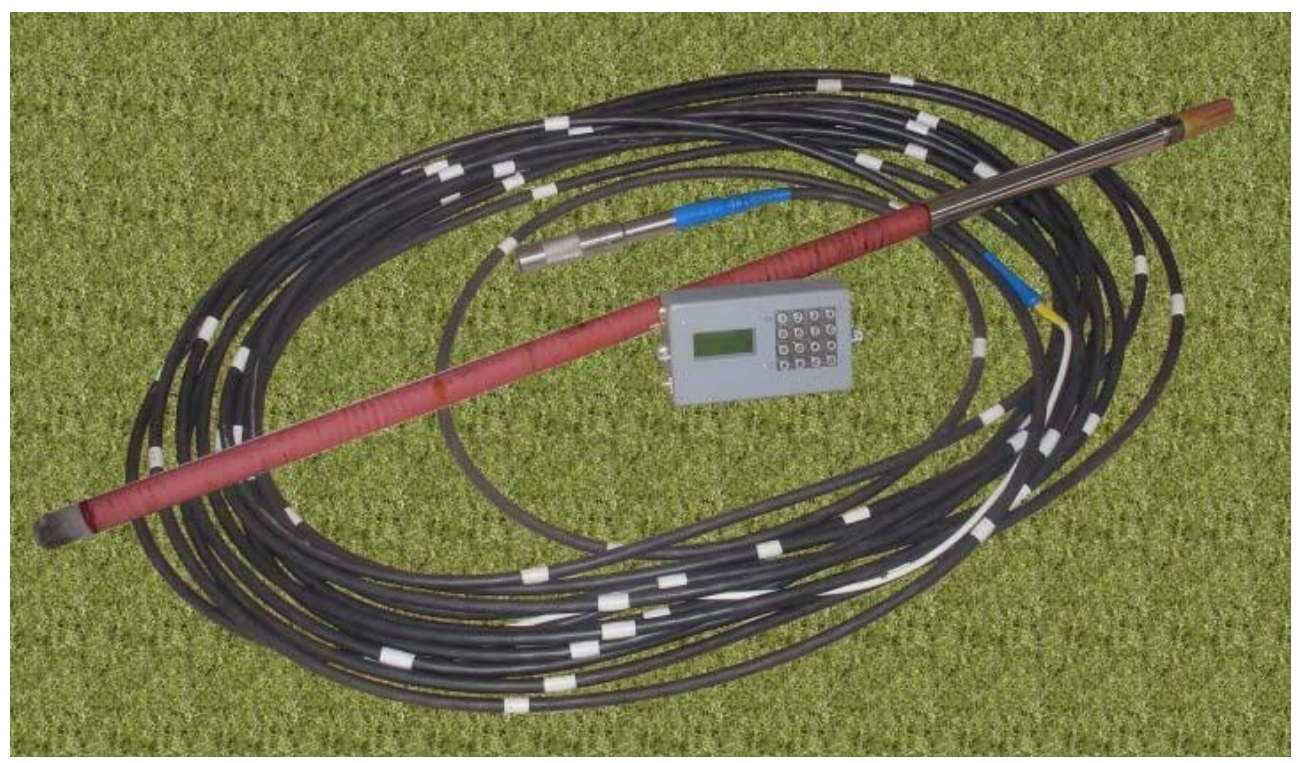

Fig. 9. PAKS-5 KK portable device 
the registration of changes in the artificially created magnetic field when moving its probe in ferrous quartzites. The measurement results of the useful component content are displayed (as a percentage) on a digital scoreboard and are automatically stored in the device memory. Logging data allows to construct a distribution model for the useful component content in the block prepared for blasting by explosives, and thus to predict the dynamics of quality change in the further exploitation of the mine. Measurement error is $\pm 1.0 \%$. The PAKS-5 KK portable device is used in the quarries of PJSC "Pivdennyi MCC", PJSC "Inhulets MCC" and in the quarries of the Mining Department of PJSC "ArcelorMittal Kryvyi Rih".

After blasting, the ore mas is mixed, which predetermines the technological control for the iron content related to magnetite in the mine using the PAKS-5 MK device (Azarian, Dryga, Tsybulevsky, \& Krivrenko, 2004) (Fig. 10). The principle of its operation is similar to PAKS-5 KK, the index of the
A microprocessor-based NAKS-PK quality and weight control system (Azarian, Byzov, 1993) can be used to control the total iron content in the ore flow on the conveyor ore transportation. The NAKS-PK system is designed for the operational control of total iron content and the mass of mineral raw material with an accuracy of $\pm 1.5 \%$. The operation of NAKSPK is based on the principle of a local information and measurement network with a central device (server), which uses a computer with special software, and peripheral measurement units (communication terminal) (Fig. 11).

Smart NAKS-PK transmitters are used as communication terminal. Communication of the server with communication terminals is carried out on a two-wire protected physical line using the main line principle. Communication terminals (smart transmitters) NAKS-PK are microprocessor devices providing control for the technological parameters of raw materials and the information exchange with

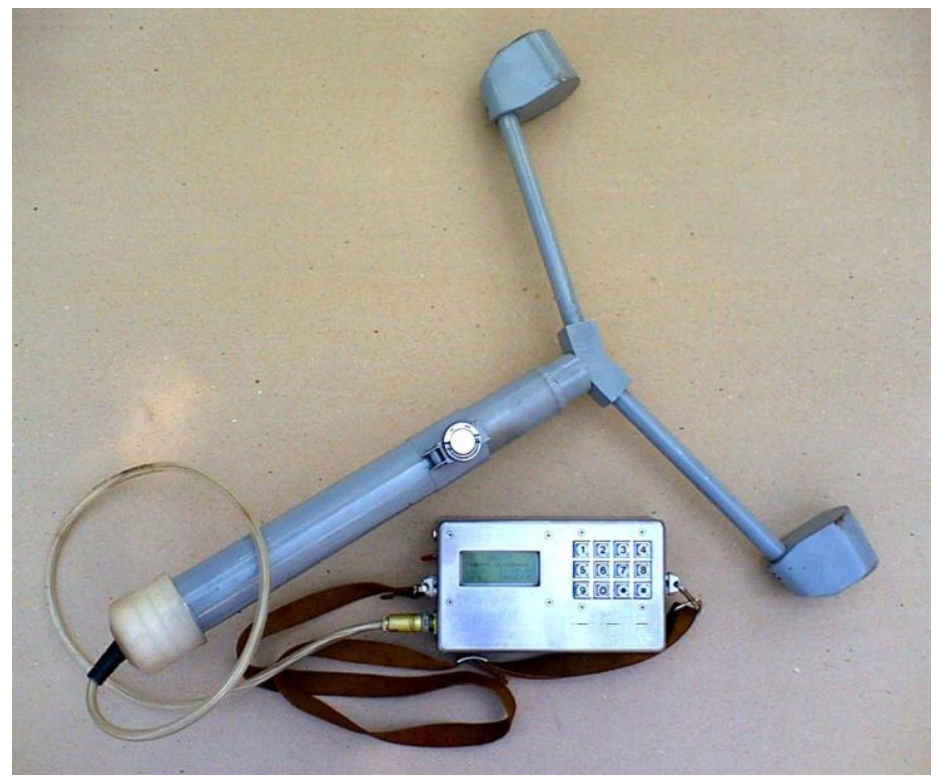

Fig. 10. PAKS-5 MK portable device

useful component content is not investigated in the wells, but on the surface of the mine, in the destroyed rock mass. The depth of the information layer is 0.5 $\mathrm{m}$. The data obtained using PAKS-5 MK is used for current compliance control of actual quality indicators with the calculated data used in the solution of the mixture calculation problem for determining the variable task. The measurement error is $\pm 1.5 \%$.

The PAKS-5 MK portable device is implemented and is successfully operated at PJSC "Pivdennyi MCC", PJSC "Central MCC", PJSC "Inhulets MCC", PJSC "Poltava MCC" and the quarries of the Mining Department of PJSC “ArcelorMittal Kryvyi Rih”. the server system. The principle of their operation is based on the registration of the flow reflected from the surface of the ore mass moving along the conveyor, using the center-shifted or lateral geometry of the relative location of the ionizing radiation sources and detectors. The recorded intensity indicator is converted into the value of the useful component content over the set measurement period. The NAKSPK control system was introduced and operates in the conditions of the surface complex of PJSC "KZRK", PJSC "SUKHA BALKA" and PJSC "ArcelorMittal Kryvyi Rih" at the entrance to the crushing and sizing plant. 


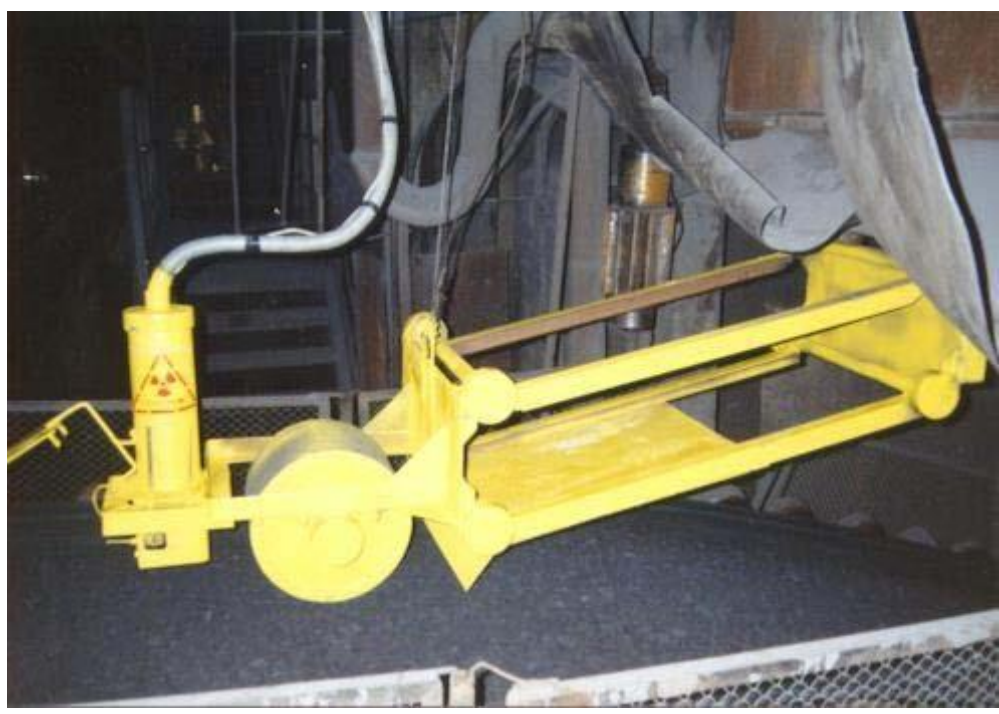

Fig. 11. Peripheral measurement unit of the NAKS-PK system

Quality control at the run-of-mines and during the shipment allows consumers to determine the total iron content (using a PAP-1 powder analyzer) and magnetite-related iron (using a magnetic DZHM-4 iron sensor) discretely, with higher accuracy.

A powder samples analyzer is designed to determine total iron content in ferrous metal samples provides accurate measurements at the as preliminary grinding of the measured material is performed, which significantly improved the accuracy of control. PAP-1 was applied at the open quarry of PJSC "Ukrmekhanobr MCC", PJSC "Central MCC". From 2018 a new modification of the powder samples analyzer of PAP-2 is applied on the open quarries of PJSC "ArcelorMittal Kryvyi Rih".

The magnetic iron sensor DZHM-4 is intended

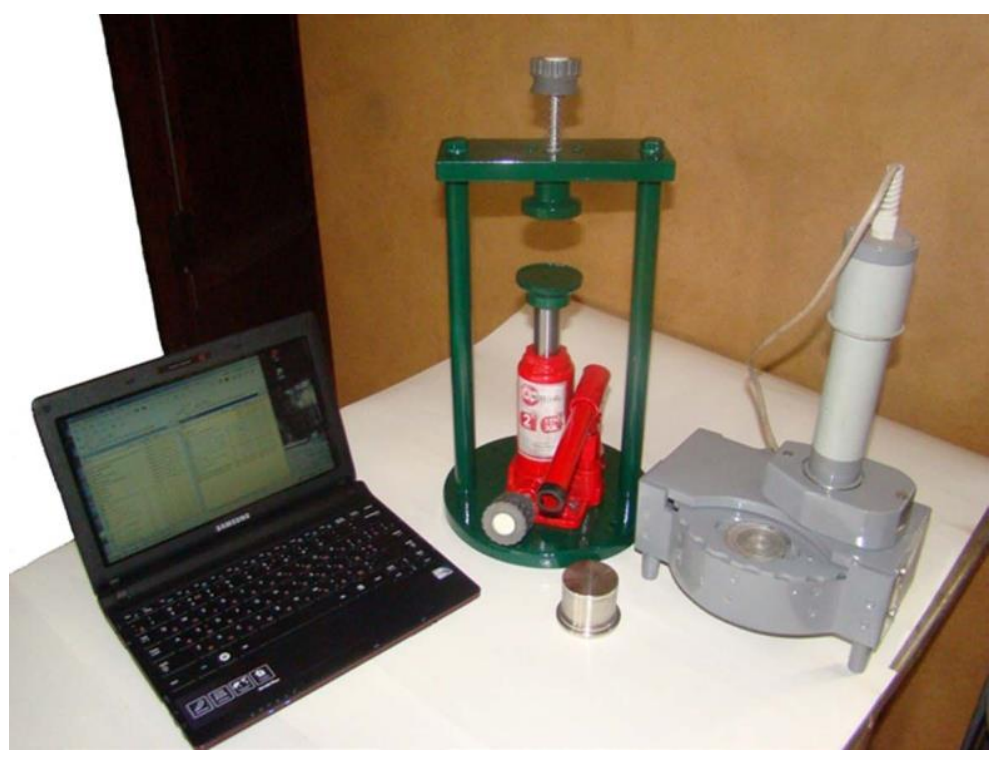

Fig. 12. Powder samples analyzer PAP-1

level of chemical analysis (Fig. 12) (Azarian, Azarian, Gritsenko, Dryga, \& Miroshnik, 2017). The measurement time is up to 60 seconds. It should be emphasized that the cost of one analysis performed using PAP-1 is two orders of magnitude lower than using the chemical analysis.

The principle of operation of the powder analyzer is similar to PAKS-5 M, but it has an improved geometry of the measurement area, as well for the express determination of the mass fraction of magnetite in iron ores (Fig. 13). DZHM-4 enables long-term storage of the obtained results in the database and their processing (the average values determination for the useful component content, graphical representation of the content distribution over time and other data processing operations). The DZHM-4 consists of a magnetic susceptibility sensor, a sample weight sensor, an electronic circuit 


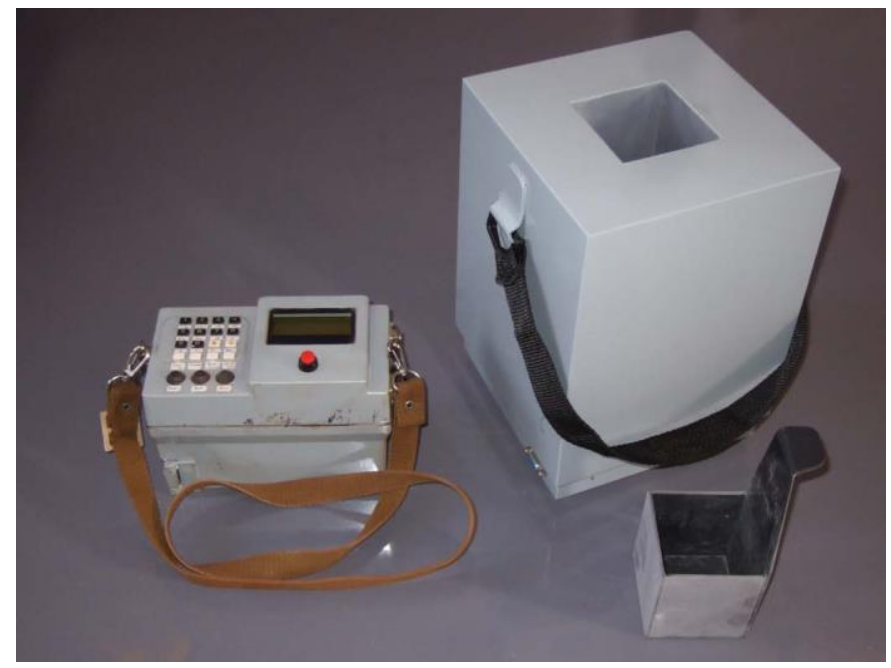

Fig. 13. Magnetic iron sensor DZHM-4

structurally assembled as a monoblock, and a measuring console. The measurement error is $\pm 1.0 \%$.

The magnetic iron sensor DZHM-4 is operated at PJSC "Inhulets MCC", PJSC "Pivdennyi MCC" and the quarries of the Mining Department of PJSC "ArcelorMittal Kryvyi Rih".

At the entrance of the processing plant, before grinding, the magnetic iron content in the ore flow on the conveyor lines is controlled by the DZHM-K

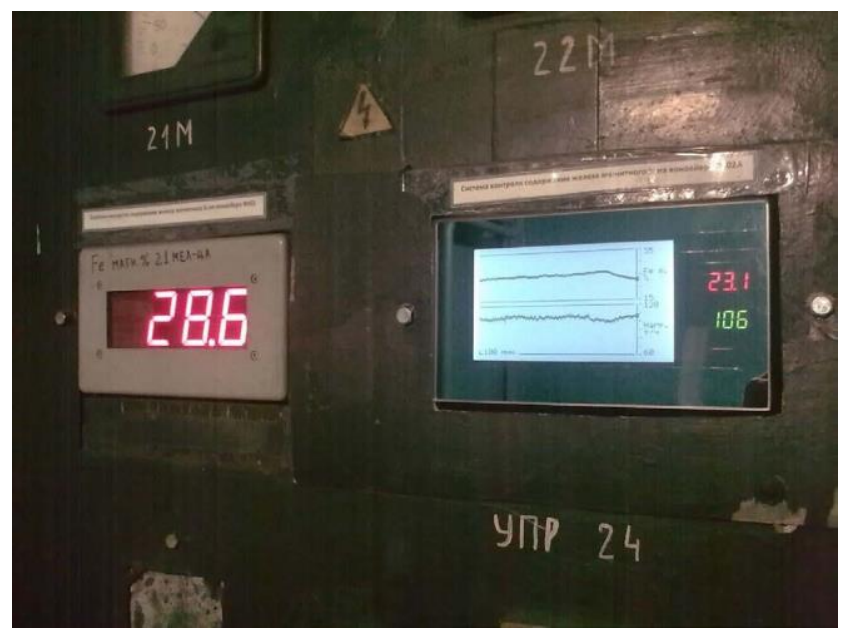

measuring coil relative to the magnetic field artificially created by induction coil in the measuring area. The DZHM-K system consists of magnetic susceptibility sensors, transducers, electronic boards, ore layer height sensors and central server height and operates on the OCP-1 sections of the Mining Department of PJSC “ArcelorMittal Kryvyi Rih" since 2007. The measurement accuracy is $\pm 1.5 \%$.

Control for the total iron content is carried out by a PAKS-5 M integrated device (Fig. 15). This device

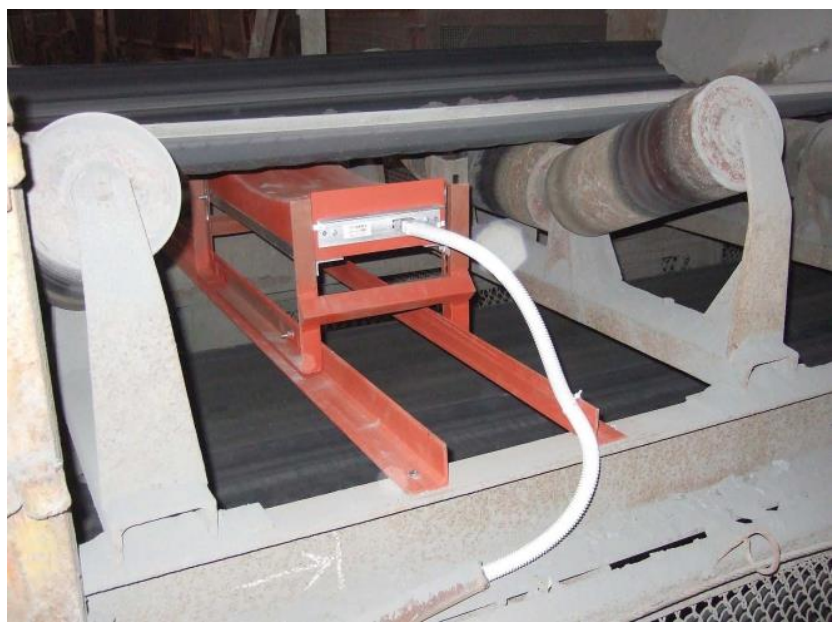

Fig. 14. DZHM-K continuous control system

continuous monitoring system (Fig. 14) (Azarian, Azarian, Dryga, Lisovyj, Tsybulevsky, Sharov, \& Shvydky, 2008).

The DZHM-K system provides real-time magnetite content determination, enables long-term storage of the obtained results in the database and their processing (the average values determination for the useful component content, graphical representation of the content distribution over time and other data processing operations). The principle of operation is based on the registration of the signal change from the has a precision measurement of total iron content lower than the PAP-1 (ПАП-1) powder analyzer $( \pm 1.5 \%)$, however, it requires less sample preparation and can be used both in laboratories and in main loading and transportation drifts and run-of-mines (Azarian, Azarian, \& Trachuk, 2012).

Comparison of the of measurements accuracy of devices and systems for operational quality control, developed in the problem-branch laboratory of Kryvyi Rih National University was carried out using the data of the standard chemical analysis of ore, which 


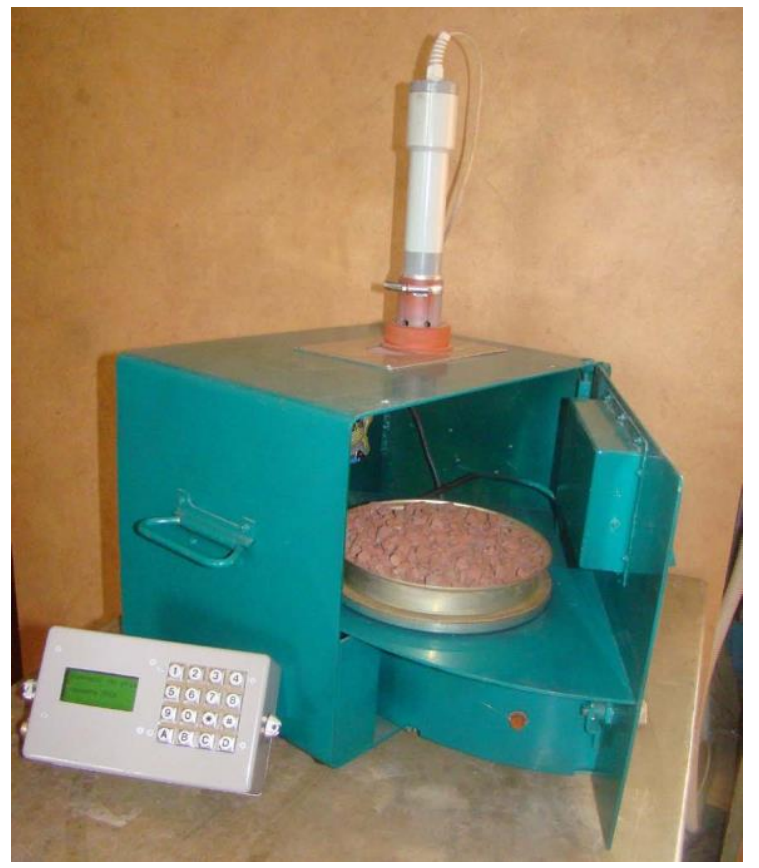

Fig. 15. Integrated device for controlling the total iron content PAKS-5 M

was performed by the State Inspectorate for Quality "Pivdenruda", as well as chemical laboratories of the Mining Department of PJSC "ArcelorMittal Kryvyi Rih", PJSC "Inhulets MCC" and PJSC "Pivdennyi MCC".

Conclusions. Theoretical works on the control and quality management for iron-containing raw materials and the practical development of the scientific team of the problem-branch laboratory of the Kryvyi Rih National University created objective prerequisites for substantiating the quality management system of mining and processing plants. Developed and implemented in the production of operational control devices cover all the basic stages of mining, provide timely and reliable information on the status and dynamics of the changes in the useful component content and to perform effective quality management on its basis and to generate MCC ore cargo traffic according to the requirements of the concentration complex, which gives an opportunity to increase competitiveness and the profit of these enterprises.

Acknowledgement. We thank the Director General of PJSC "KZRK" F.I. Karamanits and Deputy Director General for Mining of PJSC "ArcelorMittal Kryvyi Rih V.I. Tesliuk for facilitating the introduction of operational quality control means for iron-containing raw materials into mining.

\section{References}

Azarian, A., Byzov, W., 1993. Patent No. 10780 A Ukraine, G01N 23/203. Method for operational technological control of useful component content in mineral raw materials on conveyor and device for its implementation. Bulletin No. 4.

Azarian, A.,Vasilenko, V., Borodavkin, W., \& Boyko, S., 2001. Patent No. 41036 A Ukraine, G01V 5/12. Well logging station. Bulletin No. 7.

Azarian, A., Azarian, W., Gritsenko, A., Dryga, W., \& Miroshnik, D., 2017. Patent No. 119778 Ukraine, G01N 23/203. Method for determination of ferrous and heavy metals content in ore powder samples. Bulletin No. 19.

Azarian, A., Azarian, W., Dryga, W., Lisovyj, G., Tsybulevsky, Yu., Sharov, V., \& Shvydky, O., 2008. Patent No. 36662 Ukraine, G01R 33/12. A device for automatic detecting of the magnetite iron content on a conveyor. Bulletin No. 21.

Azarian, A., Azarian, W., Gritsenko, A., Dryga, W., \& Miroshnik, D., 2018. Patent No. 123234 Ukraine, G01V 5/12. Downhole device for selective gamma-gamma logging. Bulletin No. 4.

Azarian, W., Joukov, S., 2016. The problem of a generalized quality control system of the mine ore flows and its algorithmization. Bulletin of the National University of Water Management and Natural Resources Use. 4 (76), 261-270.

Azarian, A., Azarian, W., \& Cherkasov, A., 2010. The study of the physicochemical properties of ferruginous quartzites and blast hole logging. Research Report of Kryvyi Rih National University 0110U004443 №2-825-10, 32.

Azarian, A., Azarian, W., \& Cherkasov, A., 2013. Preparatory work for the development and implementation of an ore quality management software for the extraction and processing. Research Report of Kryvyi Rih National University 0113U003748 №26-947-13, 30 .

Azarian, A., Azarian, W., \& Cherkasov, A., 2015. The study of the main and additional factors affecting the accuracy of blast hole logging. Research Report of Kryvyi Rih National University 0115U003054 №2-35-15, 33.

Azarian, A., Azarian, W., \& Trachuk, A., 2014. Methods of pre- 
concentration of ferrous metal ores. Collection of scientific papers dedicated to the 110th anniversary from the birth date of V.I. Karmazin, 78.

Azarian, A., Azarian, W., \& Trachuk, A., 2012. Patent No. 73793 Ukraine, G 06Q 50/02. Operational control system for the quality of merchantable ore at shipment to consumers. Bulletin No. 19.

Azarian, A., Azarian, W., \& Trachuk, A., 2016. Modeling in mining. Textbook, 272.

Azarian, W., Joukov, S., \& Stricha, W., 2017. Study of the testing period influence for the faces of the iron ore quarry on the profit of the mining and processing enterprise. Bulletin of the National University of Water Management and Nature Resource Use. 3 (79), 42-52.

Azarian, A., Tsybulevsky, Yu., Sharov, V., Dryga, W. \& Lisovyj, G., 2008. Patent No. 84463 Ukraine, G01R 33/12. Device for determining the magnetite content in iron ores. Bulletin No. 20.

Azarian, A., Dryga, W., Tsybulevsky, Yu., \& Krivenko, A., 2004. Patent No. 6225 Ukraine, G01N 27/72. Device for the operational control of the magnetic iron mass in the rock mass. Bulletin No. 4.

Artsybashev, W., Ivanyukovich, G., 1975. Density gammagamma logging in ore deposits. Guidelines, 72.

Byzov, W., 1991. Quarry product quality management. Textbook on the specialty "Open-pit mining", 239.

Dryga, W., 2013. Continuous quality control of magnetite ores on conveyor belts in mining and processing plants. The dissertation for the degree of candidate of technical sciences, 180

Dryga, W., Shvydky, O., 2008. Laboratory research of measurement accuracy of the device for operational quality control of ferruginous quartzites. The quality of mineral raw materials, 257-262.

Gzogyan, T., 2013. Current state of engineering and technology for ore preparation of ferruginous quartzites. Changes in the structural state and physical properties of ferruginous quartzites during ore preparation. Mining Book, 55.

Joukov, S., Azarian, W., 2017. Resource prospects of Kryvbas MCCs and the concept of integrated cargo traffic management technology, generalized at the plant's scale. The quality of mineral raw materials, 564-571.

Meskon, M., 1998. Fundamentals of Management. Textbook, 800.

Morkun, W., Azarian, A., \& Azarian, W., 2015. Development of a method for determining mineral-technological varieties of iron ore using ultra-high frequency electromagnetic radiation, gamma radiation, and high-energy ultrasound. Research Report No. 0115U003030, 125. 